Scientific journal

\section{PHYSICAL AND MATHEMATICAL EDUCATION}

Has been issued since 2013.

Науковий журнал

ФІЗИКО-МАТЕМАТИЧНА ОСВІТА

Видається з 2013.
ISSN 2413-158X (online)

ISSN 2413-1571 (print)

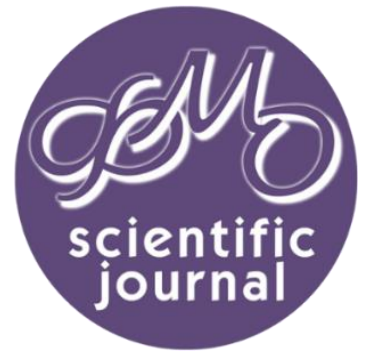

\title{
http://fmo-journal.fizmatsspu.sumy.ua/
}

Павленко М.П., Павленко Л.В., Хоменко В.Г. Розробка застосунку для проведення анкетувань та тестувань в освітньому процесі мовою Pуthon. Фізико-математична освіта. 2019. Випуск 4(22). С. 100-107.

Pavlenko M., Pavlenko L., Khomenko V. Development of application for investigation and testing in Python educational process. Physical and Mathematical Education. 2019. Issue 4(22). P. 100-107.

DOI 10.31110/2413-1571-2019-022-4-016

удк 004.415:37.091.26

М.П. Павленко

Бердянський державний педагогічний університет, Україна pavlenko.2277@gmail.com

ORCID: 0000-0003-0091-696X

л.В. Павленко

Бердянський державний педагогічний університет, Україна

liliya.pavlenko@meta.ua

ORCID: 0000-0001-7823-7399

В.Г. Хоменко

Бердянський державний педагогічний університет, Україна v_g_homenko@ukr.net

ORCID:0000-0002-7361-2169

\section{РОЗРОБКА ЗАСТОСУНКУ ДЛЯ ПРОВЕДЕННЯ АНКЕТУВАНЬ ТА ТЕСТУВАНЬ В ОСВІТНЬОМУ ПРОЦЕСІ МОВОЮ РУТНОN}

\section{АНОТАЦІЯ}

Формулювання проблеми. Сучасний освітній процес передбачає всебічне використання інформаційних технологій і зокрема систем онлайн анкетування та тестування. Однак в існуючих застосунках є ряд недоліків, які потребують удосконалення, оптимізації процесів створення, редагування та модифікації завдань.

Матеріали і методи. У розробці нового застосунку для організації й проведення анкетування та тестування було використано мову програмування Python, фреймворк Django ma наступні модулі Python: social-auth-app-django, xlrd, xlwt, django-ckeditor, django-crispy-forms, django-rosetta.

Результати. Визначенні основні параметри та характеристики, які мають бути реалізовані при створенні застосунку. 3 цією метою проаналізовані поширені програмні застосунки для анкетування та тестування: Anketolog, Google Форм, Survio, Testograf, Typeform. Визначено, що існуючі застосунки позбавлені можливості зручного створення опитувань з великою кількістю завдань, редагування та адаптації вже існуючих опитувань, імпорту та експорту завдань опитувань. у розробленому застосунку, з метою полегшення аутентифікації користувачів, використаний Google API. Cтворено динамічний фільтр для адміністрування анкет користувачів, за допомогою якого зручно знаходити необхідні відповіді, сортувати їх та збирати статистику. Реалізований механізм імпорту питань з файлу у форматі XLSX. Подальше редагування та можливість розповсюдження створених анкет, реалізовано за допомогою механізму експорту анкети та ї̈ питань у форматі XLSX. У розробленій системі анкетування та тестування передбачено механізм експорту статистичних даних у форматах CSV ma XLSX.

Висновки. Визначені недоліки та можливості в існуючих застосунках для організації й проведення анкетування та тестування. За результатами проведеного аналізу спроектовано та розроблено застосунок мовою програмування Руthоп з використанням фреймворку Django. Головною особливістю застосунку є можливість створення, редагування, експорт та імпорт анкет у форматі Microsoft Excel; одночасне опитування різних респондентів в режимі віддаленого доступу; збір та зберігання результатів, експортування результатів досліджень в різних форматах даних. Наступним кроком у подальших дослідженнях є розробка методики впровадження та використання розробленого застосунку в освітній діяльності викладачів та вчителів.

КЛЮчОВІ СЛОВА: анкетування та тестування в освітньому процесі, інформаційні технології, мова програмування Руthоп, онлайн застосунок, методика анкетування та тестування.

ВСТУП

Постановка проблеми. Сучасний освітній процес передбачає всебічне використання інформаційних технологій і зокрема систем онлайн анкетування та тестування. Адже ці освітні інструменти $є$ найбільш важливими для вивчення основних характеристик розвитку особистості студентів та учнів, дозволяють побачити зміну ситуації з досліджуваного питання і відстежити позитивну або негативну динаміку з проблем, які виникають у освітньому процесі. Використання інформаційної системи для організації опитувань та тестування можна визначити як систему організації, збору, зберігання, 
обробки і поширення інформації про діяльність педагогічної системи, що забезпечує безперервне стеження за її станом і прогнозуванням її розвитку (Майоров, 2005).

Сьогодні існує значна кількість інформаційних систем для проведення онлайн анкетування та тестування (Болюбаш, 2017). Кожна система має свій формат зберігання завдань та результатів. В процесі підготовки матеріалів для онлайн анкетування або тестування педагогічні працівники змушені витрачати значні зусилля для створення завдань, їх подальше редагування, удосконалення та підтримку для багаторазового використання. Отже виникає протиріччя між наявними функціональними можливостями інформаційних систем для проведення тестування або анкетування та потребами педагогічних працівників у зменшені часу для створення, редагування, модифікації завдань.

Аналіз актуальних досліджень. Проблематика проведення анкетування та тестування в освітньому процесі вивчається українськими та закордонними дослідниками зокрема значний вклад у теорію і практику анкетування та тестування внесли Г. Анастазі, Л. Бурлачук, Дж. Кеттелл, Ю. Нейман, К. Пірсона та ін.

Теоретичному обґрунтуванню використання засобів анкетування та тестування в освітньому процесі присвячені роботи О. Ануфрієвої, В. Бикова, І. Булах, Г. Дмитренка, О. Кас'янової, Л. Кухар, О. Спіріна та ін.

Однак в опублікованих наукових роботах, ще недостатньо висвітлюються проблеми оптимізації процесів створення, редагування та модифікації завдань в інформаційних системах онлайн анкетування та тестування.

Мета статті. Метою статті $€$ створення застосунку для проведення онлайн опитувань та тестувань в освітньому процесі, який дає змогу оптимізувати процес створення, редагування, модифікації експорту/імпорту завдань на основі врахування недоліків та можливостей існуючих застосунків

\section{ТЕОРЕТИЧНІ ОСНОВИ ДОСЛІДЖЕННЯ}

Проведення поточного та підсумкового контролів в освітньому процесі не можливий без організації та проведення анкетування та тестування. Педагогічний контроль $€$ невід'ємним компонентом технологій навчання (Павленко та Павленко, 2013, с. 45).

Розглянемо анкетування як один із основних методів дослідження в усіх сферах діяльності. «Одержану інформацію необхідно піддавати переробці, порівнянню, осмисленню, дослідженню» (Чернопятов, 2014, с. 45). Анкетування $\epsilon$ різновидом дослідного методу опитування, що дозволяє на основі письмових відповідей на запропоновані питання виявити точки зору і тенденції, які мають місце в групі респондентів (Загвязинський, 2008, с. 33). Анкетування - це письмовий вид опитування (в порівнянні з інтерв'ю, усним видом опитування).

За способом подання запитань анкети розрізняють: анкетування на основі друкованої форми, офлайн (offline) $i$ онлайн (online) анкетування. При анкетуванні на друкованій основі запитання анкети розміщуються на друкованому бланку. Офлайн анкетування є подання питань анкети респонденту у вигляді електронного документа без підключення до інтернет мережі. Респонденти заповнюють анкету, відповідають на питання відкритого та закритого типу на комп'ютері, отримані результати зберігаються і / або відправляються розробнику анкети на будь-який носій інформації і по електронній пошті для подальшої обробки отриманих даних. Онлайн анкетування $є$ розміщенням питань анкети в електронному вигляді і надання респонденту віддаленого доступу до неї.

Тестування виступає одним з об'єктивних методів вимірювання якостей і властивостей особистості, адже воно поєднує процес контролю та оцінювання. І. Булах та М. Мруга розглядають тест, як підготовлений комплекс тестових завдань певного змісту і різного рівня складності, який дає змогу оцінити знання, уміння та навички студента (Булах та Мруга, 2006).

Онлайн анкетування та тестування має ряд переваг: кількість респондентів не обмежена; сучасне зручне оформлення (інтерфейс); зручні способи розсилки запрошень на участь; немає залежності від місцезнаходження респондента; використання сучасних інструментів створення питань (завдань); зменшення матеріальних витрат на організацію та проведення; швидке і точне опрацювання результатів.

Онлайн анкетування та тестування широко використовується у практичній діяльності вчителями, викладачами, науковцями, студентами й дозволяє здійснювати: збір, структурування, обробку, аналіз інформації;

Отже, онлайн анкетування та тестування може стати найкращим джерелом інформації для дослідження освітніх процесів, якщо використовувати сучасні, доступні і прості способи їх отримання - онлайн анкетування. За допомогою онлайн анкетування можна швидко отримати інформацію і вибрати методи та шляхи вирішення для поліпшення якості освітніх послуг.

Таким чином, організація та проведення онлайн анкетування та тестування потребує використання одного 3 існуючих застосунків або розробку власного, який буде відповідати усім потребам користувачів.

\section{МЕТОДИ ДОСЛІДЖЕННЯ}

При проведенні аналізу існуючих застосунків організації й проведення анкетування та тестування 3 метою виокремлення найважливіших характеристик для професійної діяльності педагогічних працівників були використані методи аналізу, систематизації та синтезу. Що слугувало підґрунтям для визначення головних вимог, яким має відповіти сучасний застосунок для проведення анкетування та тестування.

\section{РЕЗУЛЬТАТИ ДОСЛІДЖЕННЯ}

Проаналізуємо найбільш поширені застосунки, які використовуються для організації й проведення анкетування та тестування педагогічними працівниками. Сервіси для створення анкет пропонують безкоштовні та платні послуги. Залежно від виду послуг, є різна кількість функцій, різні можливості розміщення анкет та збору статистики. Будемо розглядати лише ті функції, які надаються безкоштовно.

Розглянемо сервіс Anketolog (https://anketolog.ru/). Користувачам безкоштовних послуг $є$ можливість створити три опитування. У кожному опитуванні може бути до 10 питань. Заповнити опитування зможуть всього 50 респондентів. Система надає доступ до 13 типів питань: від простого текстового поля до сітки з оцінюванням за 100-бальною шкалою. 
Додатково можна створити сторінку вітання і завершення. До питань можна додавати коментарі або фотографії, але ліміт пам'яті на безкоштовне зберігання файлів - всього 2 МБ.

Результати опитування зберігаються в особистому кабінеті. За кожним з опитувань відображається таблиця 3 кількістю переходів, відсотком успішних заповнень і середнім часом заповнення. За бажанням можна отримувати звіти електронною поштою або завантажити звіт в форматі DOC, PDF, SPSS або XLS.

Можливість експорту та імпорту питань анкети відсутня.

Розглянемо використання застосунку Google Форм (https://forms.google.com/). Це повністю безкоштовний сервіс онлайн-опитувань. Щоб почати користуватися ним, потрібен аккаунт Google. B Google Формах можна створювати необмежену кількість опитувань будь-якої довжини. При створенні опитування доступні 11 типів питань. Серед них: текстові поля, перемикачі та випадні списки. Є можливість додавати до питань фотографії або відео з YouTube.

у анкетах створених з використанням Google Форм адаптивний дизайн: опитування зручно редагувати i заповнювати з мобільних телефонів. Результати оновлюються в реальному часі. Для відповідей на кожне питання буде створений власний графік або таблиця. Статистику можна отримувати поштою або зберегти у форматі CSV.

$€$ можливість відправити запрошення для проходження опитування на пошту, скопіювати пряме посилання на нього або вбудувати опитування на сайт. Експортувати та імпортувати анкети не можливо. Створення великих анкет не зручне.

Розглянемо сервіс Survio (http://survio.com/), який має безкоштовні послуги. До них належить необмежена кількість опитувань будь-якої довжини. При створенні опитування пропонують обрати один з 100 шаблонів готових опитувань, однак існує можливість створити власні опитування з 11 типів питань. Додатково до кожного питання можна додати опис, малюнок і відео з ҮouTube. Користувачів можливо запросити пройти опитування з використанням кнопок соціальних мереж Facebook, Twitter, LinkedIn.

Результати опитування постійно оновлюється, за процесом можливо слідкувати на відповідній сторінці облікового запису користувача. Для кожної відповіді є графік і статистика. Статистична інформація, яку надає застосунок містить дані про кількість респондентів, середній час заповнення анкети, джерела відвідувань і відсоток незакінчених відвідувань. Для розміщення опитування сервіс пропонує пряме посилання, спливаюче вікно і повне вбудовування на сайт. Застосунок не підтримає експорт та імпорт анкет та тесті.

Розглянемо сервіс Testograf (https://www.testograf.ru/), який надає пробні безкоштовні послуги. У застосунку можливо створити необмежену кількість опитувань будь-якої довжини. Опитування створюють на основі готових шаблоні з 14 типів питань. Додатково до опитування створюється привітання, текст, підказки до питань.

Результати опитувань зберігаються в особистому кабінеті користувача. До кожного питання тесту або анкети створюється окрема діаграма. Статистична інформація та результати опитування можуть бути завантажені у форматі XLS, CSV, PDF або надіслана на електронну пошту. Запросити респондентів до опитування можливо за допомогою прямого посилання, віджету або вбудувати його у сторінку власного сайту. Можливість імпортувати та експортувати анкету або тест відсутня.

Наступний застосунок Typeform (https://www.typeform.com/) також надає безкоштовні послуги. Для користувачів безкоштовних послуг $є$ три опитування, до 10 питань у кожному, доступно 15 типів питань. Кількість респондентів для кожного опитування або тесту обмежена, не більше 100 осіб. Створені тести або анкети можна інтегрувати з вебсторінками. Статистичні результати оновлюються в реальному часі та зберігаються в особистому кабінеті. (таблиця 1).

Представимо узагальнені результати аналізу застосунків організації й проведення анкетування та тестування

Таблиця 1

Порівняльна характеристика застосунків організації й проведення анкетування та тестування

\begin{tabular}{|l|c|c|c|c|c|}
\hline \multicolumn{1}{|c|}{ Застосунок } & Anketolog & Google Форм & Survio & Testograf & Typeform \\
\hline Кількість опитувань & 3 & необмежена & необмежена & необмежена & 3 \\
\hline Кількість респондентів & 50 & необмежена & 100 & 100 & 100 \\
\hline Кількість питань (завдань) & 10 & необмежена & Необмежена & 10 & 10 \\
\hline Кількість типів питань & 13 & 11 & 11 & 14 & 15 \\
\hline Обсяги зберігання даних & 2 мб & 15 Гб & - & - & - \\
\hline Експорт/імпорт анкет (тестів) & відсутній & відсутній & відсутній & відсутній & відсутній \\
\hline Завантаження звітів & $\begin{array}{c}\text { DOC, PDF, } \\
\text { XLS, SPSS }\end{array}$ & $\begin{array}{c}\text { електронна } \\
\text { пошта, XLS }\end{array}$ & - & $\begin{array}{c}\text { Електронна } \\
\text { пошта, XLS, } \\
\text { РDF, CSV }\end{array}$ & $\begin{array}{c}\text { Електронна } \\
\text { пошта, XLS, } \\
\text { PDF }\end{array}$ \\
\hline $\begin{array}{l}\text { Графічне представлення результатів } \\
\text { опитування (тестування) }\end{array}$ & немає & + & + & + & - \\
\hline
\end{tabular}

Проаналізувавши застосунки для організації й проведення анкетування та тестування можна зробити висновок, що існує одна значна проблема, це створення великих опитувань, редагування та адаптація вже існуючих опитувань. У всіх сервісів у відсутня можливість імпорту та експорту питань у зручних для користувачів форматах документів (текстових файлах, електронних таблицях, тощо).

Отже постає необхідність розробки застосунку анкетування та тестування з реалізацією функції експорту/імпорту анкет (тестів) у зручному для редагування форматі документів. Для досягнення поставленої мети було обрано мову програмування Python та веб-фреймворк Django.

Python $€$ інтерпретованою мовою програмування високого рівня загального призначення. Вона забезпечує конструкції, що дозволяють чітке програмування як у малих, так і у великих масштабах (Kuhlman, 2012). Python має систему 
зі строгою динамічною типізацією та автоматичне керування пам'яттю. Вона підтримує багато парадигм програмування, включаючи об'єктно-орієнтовані, імперативні, функціональні та процедурні, і має велику стандартну бібліотеку (Абоut Python, 2019).

Django - це вільна і відкрита веб-платформа на основі Python, яка відповідає архітектурному шаблону MVT (FAQ: General - Django documentation - Django, 2019). Вона підтримується незалежною організацією Django Software Foundation (DSF). Основна мета Django - полегшити створення складних веб-сайтів, керованих базами даних. Структура підкреслює можливість багаторазового використання і «підключення» компонентів, менше коду, швидкий розвиток, і принцип не повторювати себе (Kuhlman, 2012). Python використовується в усьому, навіть для файлів налаштувань і моделей даних. Django також надає додатковий адміністративний інтерфейс створення, читання, оновлення та видалення, який генерується динамічно через інтроспекцію і налаштовується за допомогою моделей адміністратора.

Існує велика кількість сайтів, які використовують Django, прикладклад Instagram, Mozilla, The Washington Times, Disqus, Bitbucket, Nextdoor та ін.

Веб-сайт на Django будується частинам, які утворюють окремі модулі/компоненти. Це одна з істотних архітектурних відмінностей цього фреймворку від інших. Також в ньому вбудована система реєстрації/авторизації/аутентифікації користувачів, панель адміністрування, засоби роботи з базою даних, зручна система шаблонів, гнучка система кешування, інтернаціоналізація інтерфейсу користувача, бібліотека для роботи з односкладними формами та багато інших компонентів. Різні компоненти фреймворку між собою слабо зв'язані, тому можливо використовувати свої замісники або позичити їх в інших розробників. У складі Django також присутній власний веб-сервер, який відслідковує зміни у файлах сирцевого коду та перезапускається, що зручно при розробці проекту.

Для розробки застосунку були використані наступні пакети:

- Django 2.1.5 (веб-фреймворк);

- social-auth-app-django (компонент для аутентифікації через API);

- xIrd, xlwt (засоби для роботи з документами Excel);

- django-ckeditor (текстовий редактор, застосовується в шапці форми);

- django-crispy-forms (засіб для прикрашання форм користувачів);

- django-rosetta (засіб для інтернаціоналізації інтерфейсу).

Засіб анкетування та тестування має відповідати всім характеристикам які наявні у проаналізованих застосунках організації й проведення анкетування та тестування і перевищувати їх функціональні можливості, а саме:

- поділ всіх користувачів на групи: група адміністраторів та група користувачів. Для користувачів мають бути доступні такі функції 1) можливість створювати онлайн анкету; 2) можливість вносити коригування у створену анкету; 3) можливість перегляду і / або експорту результатів як масиву даних; 4) можливість участі в анкетуванні та проходженні опитування;

- відсутність обмежень на кількості питань в анкетуванні;

- при формуванні опитування можна встановити такі типи питань: коротка текстова відповідь, текстовий блок, електронна пошта, числова відповідь, інтернет адреса, вибрі, мультивибір, дата, час, випадний список.

- можливість припинити опитування на будь-якому етапі;

- статистика опитування буде доступна тільки автору анкети;

- можливість на будь-якому етапі проведення анкетування експортувати масив даних;

- можливість створювати посилання на опитування для подальшого розсилання респондентам;

- можливість вбудовування створених анкет в інші сайти, блоги;

- публікація анкети в інтернет мережі;

- можливість встановлення часу доступності анкети в онлайні;

- можливість імпорту та експорту анкети з файлів у форматі XLSX.

Розглянемо процес створення застосунку організації й проведення анкетування та тестування мовою Python 3 використанням фреймворку Django.

Для аутентифікації користувача ми будемо використовувати Google API. Це полегшить процедуру реєстрації/авторизації - необхідно буде просто натиснути кнопку та обрати Ваш аккаунт Google. Для заміщення стандартної авторизації власною достатньо лише перевизначити шаблон сторінки (рис. 1):

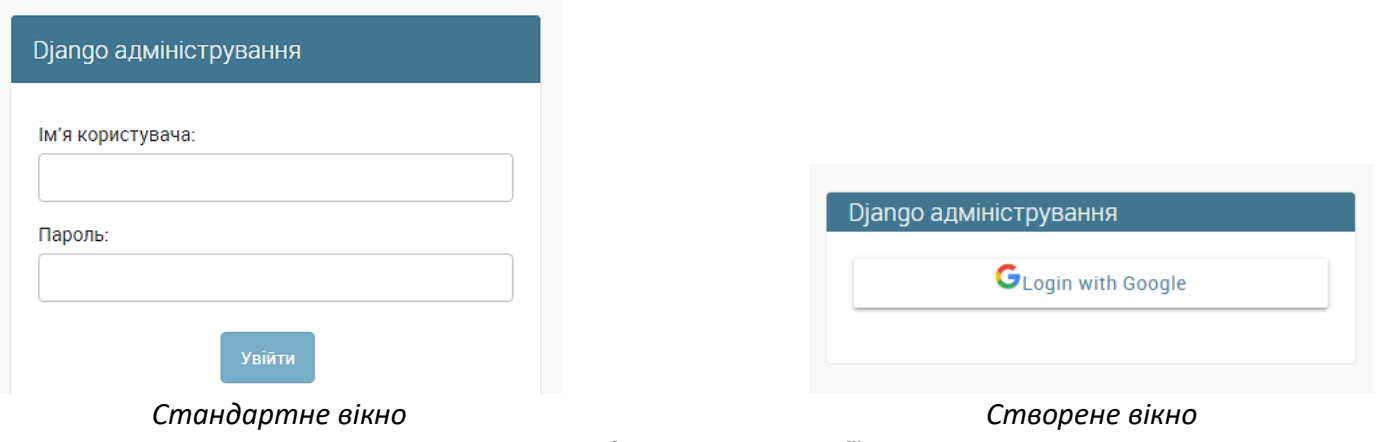

Рис. 1. Форма авторизації

Розглянемо створення форми опитування. Створимо модель сутності «Форма». Вона буде прив'язана до користувача зв'язком «багато-до-одного», це дає можливість одержувати з бази даних усі форми поточного користувача. Також створимо унікальне поле-ідентифікатор, якому система буде задавати значення в форматі UUID4 (наприклад, 
324d528d-adb2-4cc9-83ef-f066cc1318af). Інші поля моделі бази даних: назва сторінки/форми; текстове поле над формою(буде використовуватися для оформлення сторінки); текст у кнопці відправки форми; посилання для перенаправлення після відправки форми; статус форми(тип статусу один з: опублікована, чернетка); дата та час публікації форми; дата та час зняття з публікації(дуже зручно використовувати для закриття форми, наприклад, через тиждень); необхідність авторизації на сайті для доступу до форми (рис. 2).

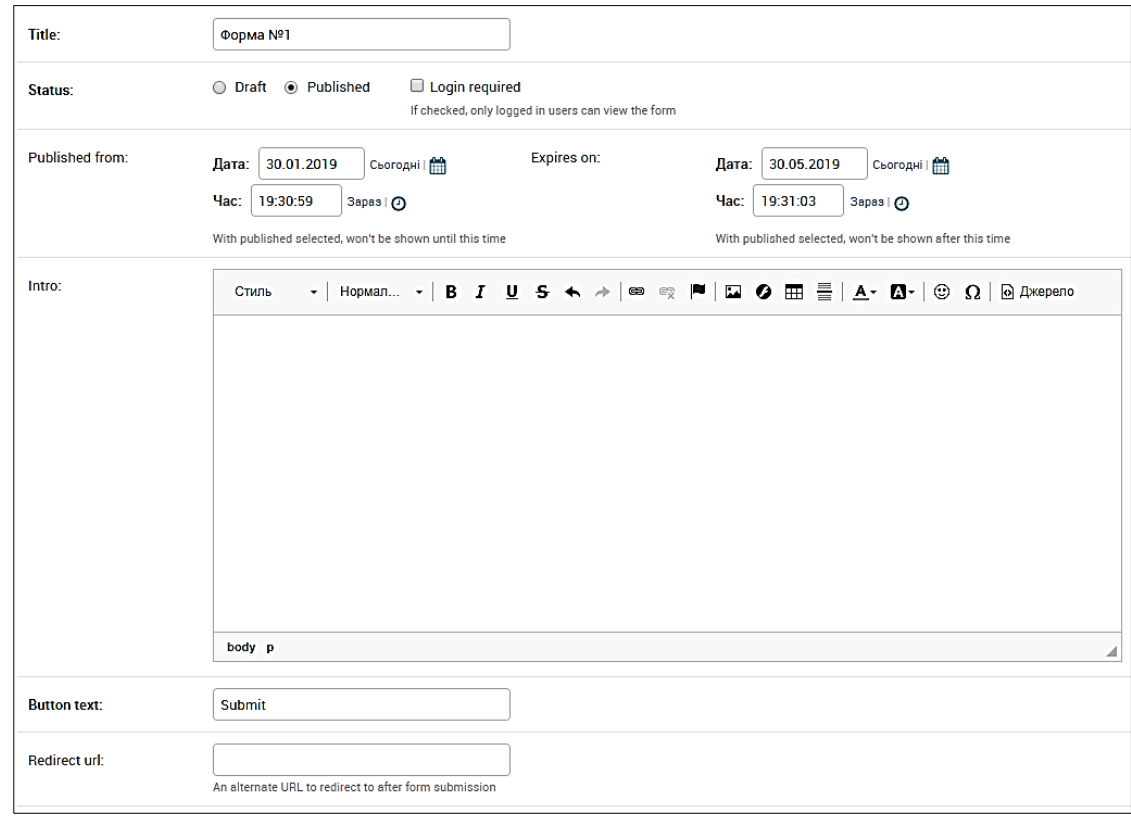

Рис. 2. Вікно створення анкети (тесту)

Поле форми будемо створювати динамічно, це одна з переваг мови програмування Python. Можемо створити абстрактний клас та використовувати його в конструкторі, це полегшить процес розробки. Скільки б типів полів ми не створили - маємо лише один метод, який адаптується автоматично. Модель бази даних «Поле форми» буде мати наступні поля: назва поля; унікальний ідентифікатор поля (потрібен для ідентифікації відповіді); тип поля (однорядкове поле, багаторядкове поле, дата, пошта, посилання, цифрове поле, випадаючий список, мульти-вибір, дата та час тощо); обов'язковість поля (вибір: Так, Ні); видимість поля (вибір: Так, Нi); варіанти відповідей (будуть працювати тільки 3 випадаючим списком, мульти-вибором та іншими подібними типами); стандартна відповідь; заповнення місця вводу; допоміжний текст.

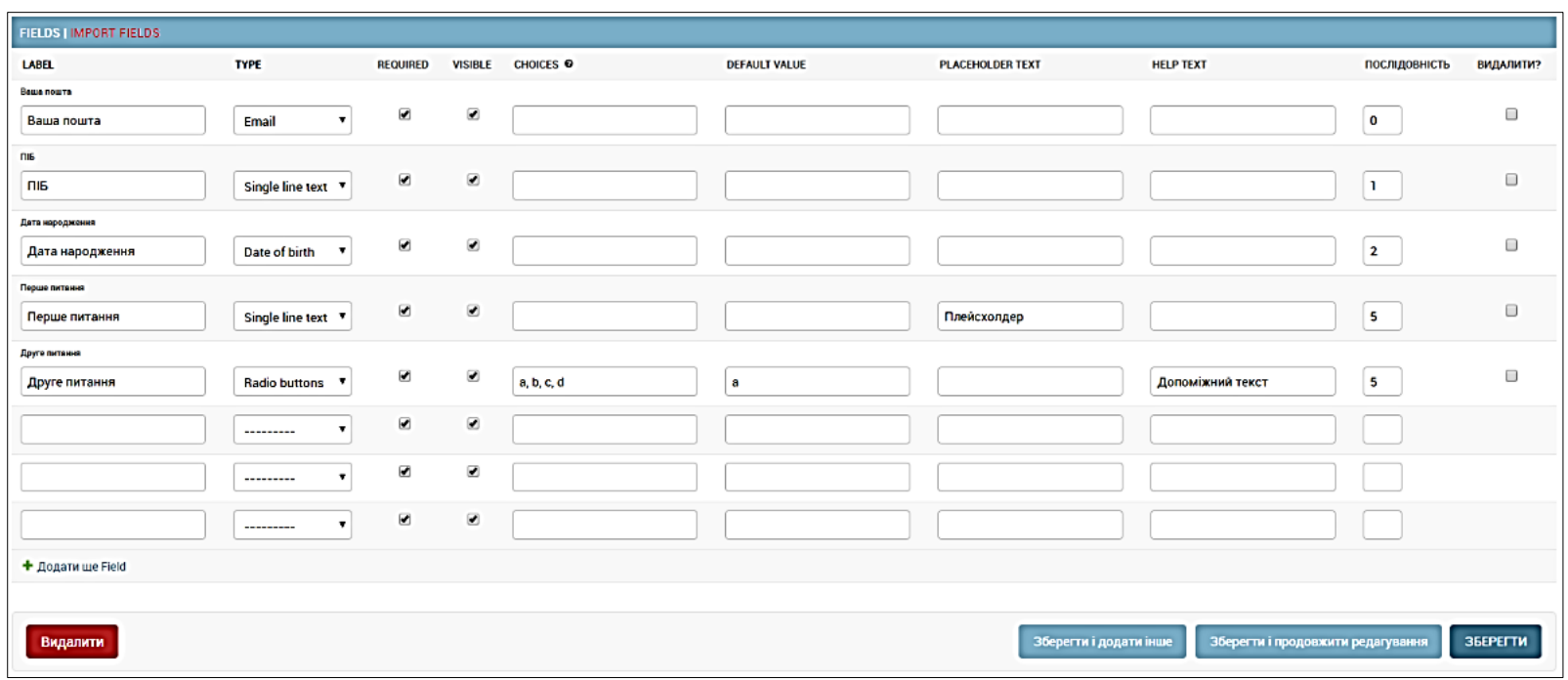

Рис. 3. Вигляд сторінки редагування/додавання форми

Модель баз даних відповідей розділена на дві. В першій частині зберігається унікальний номер форми, в другій відповіді у форматі: унікальній номер питання, відповідь у вигляді рядка.

Для конструктора форми були визначені наступні параметри: максимальна довжина рядка відповіді; максимальна довжина назви поля; використання HTML5 у генерації форми; знак, за яким будемо ділити відповіді з рядка (стандартно - кома); максимальна довжина допоміжного тексту; максимальна довжина рядка відповідей на питання.

Для динамічної генерації форми було створено новий клас, який успадковувався від стандартної форми вебфреймворку. В ньому перевизначені метод ініціалізації форми та метод збереження відповіді на форму. 
Для адміністрування форм користувачів було створено динамічний фільтр. Ним буде зручно знаходити необхідні відповіді, сортувати їх та збирати статистику. Вигляд фільтру на сторінці списку відповідей наведений на рис. 4.

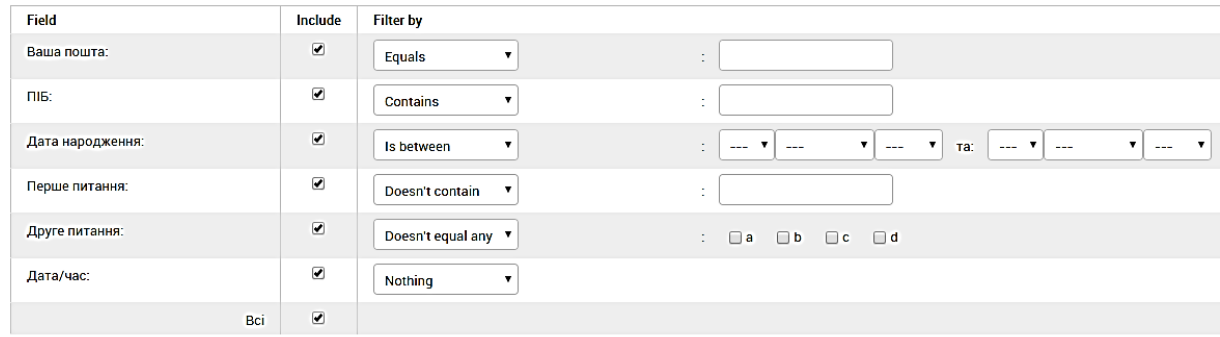

Рис. 4. Фільтр на сторінці списку відповідей

Для зручності створення анкет, реалізований механізм імпорту питань з файлу у форматі XLSX. Для подальшого редагування та можливості розповсюдження створених анкет, розроблений механізм експорту анкети та її питань у форматі XLSX.

Одною з головних функцій, яка необхідна в системах анкетування, це можливість експортувати результати анкетування та тестування. У розробленій системі анкетування реалізований механізм експорту даних у форматах CSV та XLSX. У системі реалізовано можливість видалення не потрібних відповідей анкетування.

Загальний вигляд інтернет сторінки на якій здійснюється управління відповідями анкетування (експорт, перегляд, видалення) наведений на рис. 5.

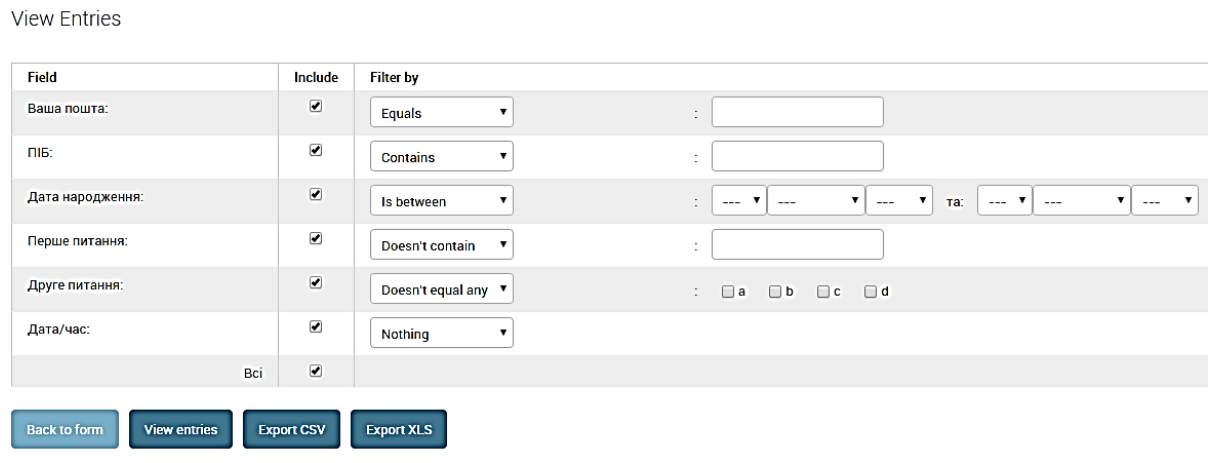

Рис. 5. Сторінка фільтрів відповідей та їх експорту

На рис. 6 наведений приклад вигляду створеної форми для проведення анкетування.

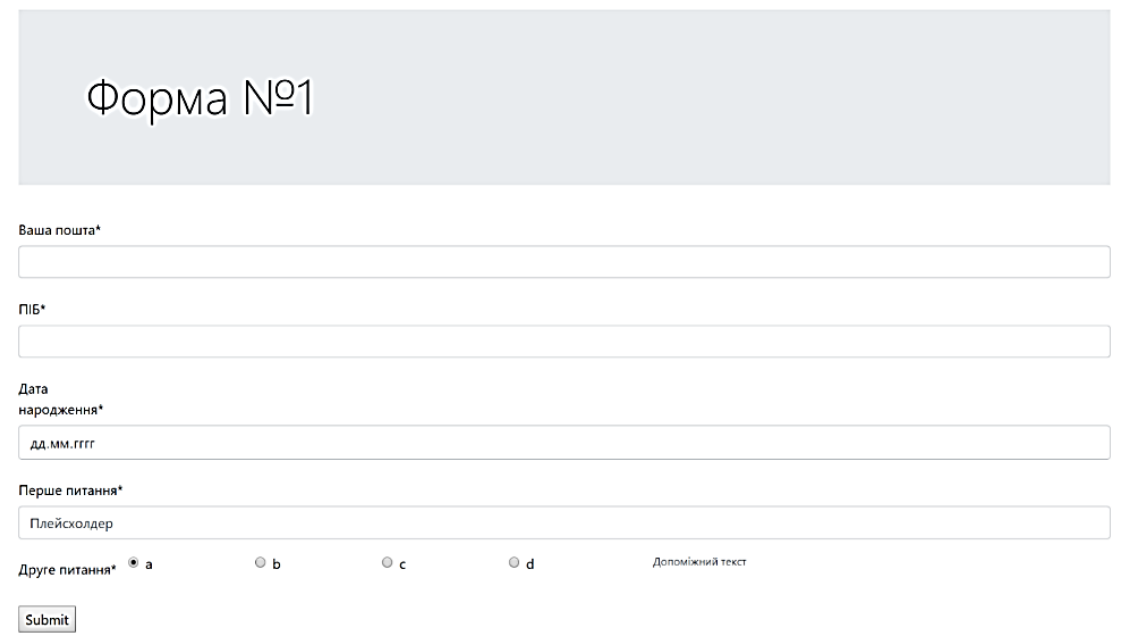

Рис. 6. Вигляд головної сторінки анкети (тесту)

В результаті проведеної роботи розроблений застосунок дозволяє створювати, публікувати, розміщувати анкети та тесту у мережі Інтернет.

Розроблений застосунок доступний за інтернете посиланням https://custom-poll.herokuapp.com/ у мережі.

\section{ОБГОВОРЕННЯ}

Розроблений застосунок для організації й проведення анкетування та тестування має ряд переваг у порівнянні 3 вже існуючими. 
Зручність розсилки та публікації анкети в мережі Інтернет, а саме: вбудовування тесту або анкету у будь-яку вебсторінку, розсилка електронного посилання на тест або анкету електронною поштою, поширення посилання у соціальних мережах.

При проведенні контролю знань важливим є обмеження часу доступу респондентів до тесту або анкети, дана функція реалізована у розробленому застосунку.

Швидкість опрацювання результатів забезпечується вбудованими засобами побудови діаграм та графіків для швидкої інтерпретації результатів.

Доступ до результатів опитування або тестування може бути здійснений на сторінці автора або за допомогою експорту отриманих даних у форматах XLSX та CSV.

Спрощена реєстрація для створення анкет та тестів й проходження опитувань забезпечується розробленою реєстрацією за допомогою облікового запису Google.

у застосунку врахована необхідність експорту/імпорту анкет у форматі XLSX для їх зручного редагування користувачами у програмі Microsoft Excel.

\section{ВИСНОВКИ ТА ПЕРСПЕКТИВИ ПОДАЛЬШОГО ДОСЛІДЖЕННЯ}

Використання розробленого застосунку перетворює процес анкетування та тестування у доступний та зручний спосіб одержання інформації, яка дозволяє обрати шляхи подальшого розвитку та удосконалення освітньої діяльності у закладах освіти.

В ході дослідження визначені недоліки та можливості існуючих застосунків для організації й проведення анкетування та тестування. На основі результатів аналізу розроблено застосунок мовою програмування Руthon 3 використанням фреймворку Django, що підтримує створення і редагування анкет; процеси одночасного опитування різних респондентів в режимі віддаленого доступу; збір та зберігання результатів, експортування результатів досліджень в різних форматах даних (файли у форматі Microsoft Excel та файли у форматі значень розділених комою - формат CSV), експорт та імпорт анкет у форматі Microsoft Excel.

У подальших дослідженнях плануємо розробити методику впровадження та використання розробленого застосунку в освітній діяльності викладачів та вчителів.

\section{Список використаних джерел}

1. Болюбаш Н. М. Педагогічне тестування в системі LMS Moodle. Інформаційні технології і засоби навчання, 2017. Т. 60, вип. 4. С. 116-127. URL: http://nbuv.gov.ua/UJRN/ITZN_2017_60_4_12 (Дата звернення 2.11.2019).

2. Булах І. Є., Мруга М. Р. Створюємо якісний тест. Київ: Майстер-клас, 2006. 160 с.

3. Майоров А. Н. Мониторинг в образовании [Изд. 3-е, испр. и доп.]. М. : Интеллект-Центр, 2005. 424 с.

4. Павленко М.П., Павленко Л.В. Системний підхід у дослідженні та організації коригуючого контролю. Науковий часопис НПУ імені М.П.Драгоманова. Серія 16. Творча особистість учителя: проблеми теорії і практики: збірник наукових праць. К. : Вид-во НПУ імені М. П. Драгоманова, 2013. Вип. 19 (29). С. 238-246.

5. Педагогический словарь: учебное пособие для студ. высш. учеб. заведений / под ред. В. И. Загвязинского, А. Ф. Закировой. М. : Академия, 2008. 352 с.

6. Чернопятов А. М. Процессное обучение с применением анализа превосходства. Инновационная экономика. 2014. Вып. 3(16). С. 46.

7. About Python. Python Software Foundation. URL: https://www.python.org/about (Last accessed: 2.11.2019).

8. FAQ: General - Django documentation - Django. URL: https://docs.djangoproject.com/en/dev/faq/general/ (Last accessed: 2.11.2019).

9. Kuhlman D. A Python Book: Beginning Python, Advanced Python, and Python Exercises. URL: https://web.archive.org/web/20120623165941/http://cutter.rexx.com/ dkuhlman/python_book_01.html (Last accessed: 2.11.2019).

\section{References}

1. Boliubash, N. M. (2017). Pedahohichne testuvannia v systemi LMS Moodle [Pedagogical testing in the LMS Moodle system]. Informatsiini tekhnolohii i zasoby navchannia - Information Technologies and Learning Tools, (60, issue 4), 116-127. Retrieved from http://nbuv.gov.ua/UJRN/ITZN_2017_60_4_12 [in Ukrainian].

2. Bulakh, I. Ye., \& Mruha, M. R. (2006). Stvoriuiemo yakisnyi test [Create a quality test]. Kyiv: Maister-klas [in Ukrainian].

3. Majorov, A. N. (2005). Monitoring v obrazovanii [Education Monitoring]. Moskva: Intellekt-Tsentr. [in Russian].

4. Pavlenko, M. P., \& Pavlenko, L. V. (2013). Systemnyi pidkhid u doslidzhenni i orhanizatsii koryhuiuchoho kontroliu [Systematic approach to research and organization of corrective control]. Naukovyi chasopys NPU imeni M.P.Drahomanova - Scientific journal of NPU of Dragomanov, (29, issue 19), 238-246.

5. Zagvjazinskij, V.I. (Ed.). (2008). Pedagogicheskij slovar [Pedagogical dictionary]. Moskva: Akademija. [in Russian].

6. Chernopjatov, A. M. (2014). Processnoe obuchenie s primeneniem analiza prevoshodstva [Process Learning Using Excellence Analysis]. Innovacionnaja jekonomika - Innovative economy, 3(16), 46. [in Russian].

7. About Python. (n.d.). www.python.org. Retrieved from https://www.python.org/about [in English].

8. FAQ: General - Django documentation - Django. (n.d.). docs.djangoproject.com Retrieved from https://docs.djangoproject.com/en/dev/faq/general/ [in English].

9. Kuhlman, D. A Python Book: Beginning Python, Advanced Python, and Python Exercises. Retrieved from https://web.archive.org/web/20120623165941/http://cutter.rexx.com/ dkuhlman/python_book_01.html [in English]. 
DEVELOPMENT OF APPLICATION FOR INVESTIGATION AND TESTING IN PYTHON EDUCATIONAL PROCESS Liliia Pavlenko, Maksym Pavlenko, Vitalii Khomenko

Abstract. Berdiansk State Pedagogical University, Ukraine

Formulation of the problem. The modern educational process involves the all-round use of information technology and online questionnaires and testing systems in particular. However, existing applications have a number of drawback that require improvement, optimization of the creation process, editing and modification of tasks.

Materials and methods. Python programming language, Django framework, and the following Python modules were used to develop the new questionnaire and test application: social-auth-app-django, xlrd, xlwt, django-crispy-forms, django-rosetta.

Results. The basic parameters and characteristics that must be implemented when creating the application are identified. With this purpose, common software applications for questionnaire and testing were analyzed: Anketolog, Google Forms, Survio, Testograf, Typeform. It is determined that existing applications lack the ability to conveniently create polls with many tasks, edit and adapt existing polls, import and export polls. In the developed application, Google API was used to facilitate user authentication. A dynamic filter has been created to administer user profiles, with which you can conveniently find the answers you need, sort them and collect statistics. An XLSX file import mechanism has been implemented. Further editing and distribution of the created questionnaires was realized with the help of exporting the questionnaire and its questions in XLSX format. The developed questionnaire and testing system provides a mechanism for exporting statistics in CSV and XLSX formats.

Conclusions. Drawbacks and opportunities of existing applications for organizing and conducting questionnaires and testing are identified. As a result of the analysis, Python programming language was designed and developed using Django framework. The main specific feature of the application is the ability to create, edit, export and import questionnaires in Microsoft Excel format; simultaneous polling of different respondents in remote access mode; collecting and storing results, exporting research results in different data formats. The next step in further research is to develop a methodology for implementing and using the developed application in the educational activities of university and school teachers.

Key words: questionnaire and testing within the educational process, information technology, Python programming language, online application, questionnaire and testing methodology. 